\title{
ІНТЕГРАЦІЯ ІНОЗЕМНИХ МОВ ЗА ПРОФЕСІЙНИМ СПРЯМУВАННЯМ ІЗ ДИСЦИПЛІНАМИ ГУМАНІТАРНОГО ЦИКЛУ
}

Євтушенко Н. І. Інтеграція іноземних мов за професійним спрямуванням Із дисциплінами гуманітарного циклу.

У статті здійснено спробу проаналізувати інтегрований підхід у навчанні й довести, що інтегроване навчання іноземних мов за професійним спрямуванням з дисциплінами гуманітарного циклу дає набагато кращий результат у порівнянні з традиційним вивченням предметів.

Ключові слова: інтегрований підхід, іноземні мови за професійним спрямуванням, гуманітарні дисципліни, пізнавальна самостійність майбутніх учителів.

Евтушенко Н. И. Интеграция иностранных языков профессиональной направленности с дисциплинами гуманитарного цикла.

В статье сделана попытка проанализировать интегрированный подход в обучении и доказать, что интегрированное обучение иностранным языкам профессиональной направленности с дисциплинами гуманитарного цикла дает гораздо лучший результат по сравнению с традиционным изучением предметов.

Ключевые слова: интегрированный подход, иностранные языки профессиональной направленности, гуманитарные дисциплины, познавательная самостоятельность будущих учителей.

Evtushenko N. I. Integration of foreign languages of professional orientation with humanitarian disciplines.

The article deals with attempts of analyzing of integrated approach in learning and proving that integrated teaching of foreign languages of professional orientation with humanitarian disciplines gives a much better result than the traditional one of subjects.

Key words: integrated approach, foreign languages of professional orientation, humanitarian disciplines, cognitive independence of future teachers.

Сприятливе підгрунтя для досягнення логічного взаємозв'язку всіх форм навчання в умовах ВПНЗ створюється, на нашу думку, забезпеченням інтеграції іноземних мов за професійним спрямуванням 3 дисциплінами гуманітарного циклу на основі активного залучення майбутніх учителів до навчально-пізнавальної та навчально-дослідницької діяльності, оптимального поєднання форм і методів навчання. О. Абдулліна [1], вивчаючи свого часу проблему загальнопедагогічних знань у педагогічній теорії, стверджувала, що такі знання розглядаються, виходячи $з$ функції самої педагогічної науки й зі структури професійної діяльності вчителя, та мають подвійну спрямованість: як методологічного фундаменту професійної діяльності й як безпосереднього інструменту практичних дій. Інші автори систему знань студента ВПНЗ розглядають як: взаємозв'язок методологічних, науково-теоретичних i практичних знань (Н. Кузьміна, В. Сластьонін); поєднання науково-теоретичних і конструктивно-технічних чи нормативних знань, які регулюють діяльність майбутнього вчителя (Л. Рибалко); як поєднання знань фундаментальних та інструментальних (С. Архангельський); теоретичних і практичних (Ю. Кулюткін).

Mema cmammi - проаналізувати інтегрований підхід у навчанні й з'ясувати можливості та результат інтеграції іноземних мов професійного спрямування з дисциплінами гуманітарного циклу.

Сучасна педагогічна наука стверджує, що для продуктивного засвоєння студентом знань і для його інтелектуального розвитку важливе значення має встановлення широких зв'язків як між різними розділами курсу, який вивчається, так і між різними дисциплінами загалом. Досвід показує, що інтегроване навчання, за якого матеріал доповнюється та повторюється іншими напрямами, дає набагато кращій результат порівняно $з$ традиційним вивченням дисциплін. Інтегративний підхід до викладання сприяє виробленню системи знань, розвиває здібності до їх переносу в інші галузі. У формуванні наукового світогляду, прикладних умінь провідна роль зв'язків між спорідненими навчальними предметами є загальновизнаною. Однак у контексті розв'язання проблеми формування пізнавальної самостійності майбутнього вчителя набуває 
актуальності реалізація тих зв'язків, що об'єктивно існують у багатовимірному освітньому просторі між різнорідними знаннями.

Ідея педагогічної інтеграції, на думку вітчизняних дослідників, не є новим явищем у вітчизняній педагогіці; варто пригадати створений К. Ушинським аналітико-синтетичний метод навчання грамоти, уроки мислення у природі В. Сухомлинського, уроки мистецтва Д. Кабалевського, педагогічну теорію співробітництва Ш. Амонашвілі, що побудовані на засадах інтеграції. 3-поміж видів інтеграції науковці виокремлюють внутрішньопредметну та міжпредметну, горизонтальну й вертикальну.

3 позиції практичної реалізації інтеграції видається цілком виправданим застосування інтегрованих лекцій, семінарів, практичних занять, інтегрованих спецкурсів (наприклад, іноземна мова та українська література для студентів філологічних спеціальностей, іноземна мова й історія тощо).

На разі підкреслимо, що в сучасних європейських країнах інтеграційні процеси в навчанні набули значного поширення й охоплюють створення узгоджених міжпредметних програм, міжпредметних внутрішньо інтегрованих навчальних курсів і відповідних підручників.

Нижче пропонується концептуальна схема інтеграції змісту основного й спорідненого предметів. На грунті визначення суміжних (дотичних) тем викладач основної дисципліни спільно зі студентом-асистентом (обирається з найбільш фахово обізнаних студентів групи чи підгрупи) визначають мету та добирають (укладають) практичний матеріал заняття, у такий спосіб відбувається реалізація спільного змістового блоку. У психолого-педагогічних дослідженнях указується на той факт, що професійна кваліфікація повинна містити не тільки професійну майстерність, але й професійну соціалізацію. Розв'язання цього питання визначає два основних напрямки формування змісту навчання у вищому педагогічному навчальному закладі.

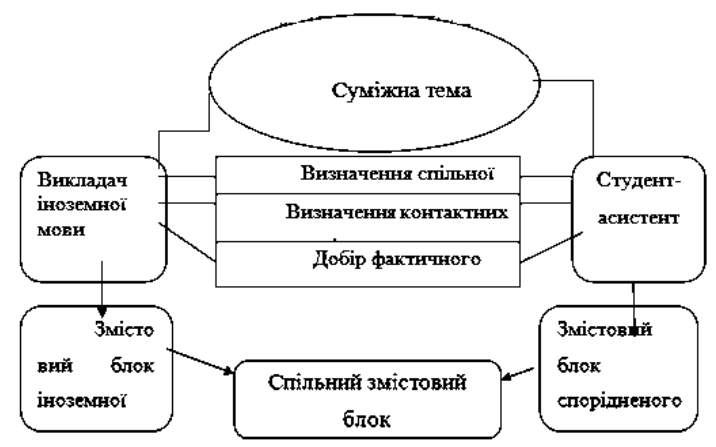

Рис.1. Концептуальна схема інтеграції іноземної мови і спорідненого предмета

По-перше, це формування особистості самого студента, розвиток його індивідуальних якостей та особливостей, по-друге - засвоєння ним знань зі спеціальності, які в майбутньому стануть засобом і змістом його професійної діяльності. Нині вища освіта страждає ізольованістю іноземних мов за професійним спрямуванням від загальногуманітарного циклу дисциплін, ця ізольованість негативно впливає на становлення особистості фахівця, який не має навичок екстраполяції досягнень у галузі інших наук у сферу своєї діяльності. Від інтергації дисциплін багато в чому залежить інтелектуально-творчий потенціал особистості; вона повинна спрямовуватись на виховання індивіда як активного й вольового суб'єкта, здатного до самостійних дій у навчанні. Сучасні методи викладання гуманітарних дисциплін потребують удосконалення. Це відчувається під час спостережень за студентами, які спроможні переказати все те, що їм викладали, але не в змозі використати здобуті знання в новій ситуації, їхні знання скоріше визначаються шириною охопленння, ніж глибиною розуміння. Вищі педагогічні навчальні заклади повинні вчити студента висловлювати власну думку, зобов'язані навчити мислити, а не лише запам'ятовувати й відтворювати інформацію.

На основі пізнавальної діяльності майбутні вчителі засвоюють стрижневі поняття й виявляють для себе сутність предметів гуманітарного циклу, набувають практичних умінь, 
знань і навичок. Навчальний матеріал (різний за типологією, дидактичною складністю, специфікою викладання) у пізнавальній діяльності відіграє роль тієї основи, на якій грунтуються узагальнені, фундаментальні й теоретичні поняття, категорії.

Ш. Ганелін розкрив шляхи формування системи знань (зокрема й гуманітарних) засобом послідовного здійснення взаємозв'язків між провідними ідеями та поняттями суміжних курсів. Під системністю знань він розуміє взаємопов'язані знання не тільки в межах одного предмета, але й у межах певного циклу предметів як зв'язок між різними циклами. Він уважав, що істинно свідомі знання неможливі без установлення міжпредметних спадкоємних знань [3].

Очевидно, що деякі науковці використовують терміни «інтеграція навчальних дисциплін» та «міжпредметні зв'язки» як синонімічні. Вважаємо за потрібне конкретизувати зміст кожного терміна. У «Великому тлумачному словнику сучасної української мови» інтеграція визначається як «доцільне об'єднування та координація дій різних частин цілісної системи» [2, с. 401], а на сторінках «Педагогічного словника» С. Гончаренка міжпредметні зв'язки тлумачаться як «взаємне узгодження навчальних програм, зумовлене системою наук і дидактичною метою. Міжпредметні зв'язки відображають комплексний підхід до виховання й навчання, який дає можливість визначити як головні елементи змісту освіти, так і взаємозв'язки між навчальними предметами» [4, с. 210].

Зважаючи на мету статті, інтеграцію іноземних мов за професійним спрямуванням 3 дисциплінами гуманітарного циклу ми визначаємо як координацію змісту, програмного й методичного забезпечення заздля створення оптимального середовища для формування пізнавальної самостійності студентів. Використання міжпредметних зв'язків $є$ іманентною частиною інтеграції навчальних дисциплін.

Деякі науковці вбачають в інтеграції навчальних дисциплін не тільки засіб формування гнучкої та продуктивної думки, але й узагальнених способів дій (О. Кабанова-Меллєр, I. Малафіїк, М. Махмутов). Навчальний процес значно активізується, якщо поряд з іншими чинниками використовуються міжпредметні зв'язки. У тих, хто навчається, виявляються нові резерви сприйняття, мовлення, взаємозв'язків логічного й образного мислення в навчальному пізнанні. Розвивальна функція міжпредметних зв'язків виявляється у формуванні пізнавальної активності, самостійності навчальної діяльності й інтересів учнів. Формувальна функція міжпредметних зв'язків полягає в тому, що вони створюють умови для формування світогляду, пізнавальної активності та самостійності.

Інтеграція дисциплін потребує координації діяльності викладачів різних предметів, вивчення навчальних програм із споріднених предметів, взаємовідвідування занять. Міжпредметні завдання розв'язуються шляхом постійного аналізу й порівняння знань, що належать до різних галузей науки. Основним способом міжпредметного пізнання $є$ перенесення знань 3 однієї предметної галузі в іншу. Узагальнення знань і способів дій, підвищуючи активність й успішність діяльності, посилює ії пізнавальну мотивацію, особливо під час розв'язання творчих, нестандартних задач і завдань. У такому випадку у студентів зростає інтерес до власного процесу мислення, до його операційного складника. Інтеграція навчальних дисциплін, безсумнівно, розкриває загальні методи пізнання, створює в навчальному процесі єдність змістової, операційної та мотиваційної сторін пізнавальної діяльності, активізує й об'єднує, систематизує знання, одержані студентами 3 різних джерел. Об'єктами пізнавальної діяльності на інтегративній підставі стають питання суміжного характеру, загальні для предметів ідеї, теорії, факти, правила. При цьому виникають пізнавальні суперечності, не властиві суто предметному навчальному пізнанню й зумовлені певною роз'єднаністю навчальних програм, що, у свою чергу, призводить до дискусій, активізує пізнавальну самостійність студентів.

Ми поділяємо точку зору тих науковців (А. Коломієць, М. Махмутов), які вважають, що основні засоби розвитку пізнавальної самостійності полягають у висуненні та розв'язанні міжпредметних навчальних проблем i можуть утілюватися в постановку інтегрованих пізнавальних завдань, створення проблемних ситуацій, розв'язання яких можливе лише через узагальнення знань 3 різних навчальних предметів, розв'язання комплексних завдань, орієнтованих на творчий пошук.

Розв'язуючи різноманітні проблеми, що вимагають залучення знань студентів з різних предметів, викладач активізує в них мотиви пізнавальної діяльності, а саме: усталену мотивацію, яка залежить від інтересів, взаємин, настанов, які склалися попередньо; 
процесуальну мотивацію, що виникає у процесі виконання предметних дій, пов'язаних 3 цілепокладанням; ситуативну та пізнавальну мотивацію, яка стимулює перенесення знань зі сфери вивчення одних предметів у сферу вивчення інших і тим самим пробуджує інтерес до пізнання. Саме таким чином відбувається організація та здійснення навчально-пізнавальної та навчально-дослідницької діяльності. У педагогічній літературі специфіка такої пізнавальної діяльності знаходить відображення у відповідній термінології.

Із теорії діяльності О. Леонтьєва випливає, що одна діяльність від іншої відрізняється ії предметом, саме предмет діяльності і надає їй певне спрямування [5]. Предметом навчальнодослідницької діяльності є пошук, пояснення й обгрунтування закономірних зв'язків і відношень тих факторів, явищ, процесів, які експериментально спостерігаються або теоретично аналізуються. Таку діяльність організовує викладач із використанням, у більшості випадків, дидактичних засобів непрямого та перспективного управління діяльністю студентів, у яких домінує самостійне застосування учнями наукових методів пізнання. У результаті такої діяльності студенти активно оволодівають знаннями, розвивають свої дослідницькі вміння та здібності.

Вивчення психолого-педагогічної літератури дає можливість виявити певну сукупність ознак, які розкривають сутність навчально-пізнавальної та навчально-дослідницької діяльності. Така діяльність зорієнтована на розв'язання навчальних проблем (М. Махмутов, О. Матюшкін, В. Крутецький), творчих задач і завдань (Ю. Кулюткін, В. Андреєв). Навчально-пізнавальна діяльність - педагогічно керована діяльність, але педагогічне керівництво здійснюється у більшості випадків на основі засобів непрямого та перспективного управління. У процесі навчально-дослідницької діяльності самоуправління особистості відбувається на основі евристики, евристичних програм, вказівок найбільш загального характеру (Ю. Кулюткін, Л. Фрідман, А. Хуторський); успішність такої діяльності досить часто залежить не стільки від рівня розвитку формально-логічних (усвідомлених), скільки від евристичних, інтуїтивних процесів інтелектуальної діяльності (С. Кульневич, І. Шайдур, В. Шахов).

Безумовно, навчально-пізнавальна та навчально-дослідницька діяльність студентів $\epsilon$ найбільш ефективною формою підготовки якісно нових спеціалістів в умовах ВПНЗ 3 урахуванням вимог сьогодення та подальших перспектив фахового розвитку й становлення молодого спеціаліста. За правильного керівництва та відповідного добору засобів вона максимально розвиває індивідуальні здібності, дослідницькі навички, сприяє виявам ініціативності й тим самим створює сприятливу основу для формування пізнавальної самостійності майбутніх учителів.

Отже, інтеграція іноземних мов за професійним спрямуванням 3 дисциплінами гуманітарного циклу активізує процес засвоєння, позитивну мотивацію навчання, спонукаючи до постійного застосування знань і способів дій. Використання знань із суміжних предметів це їх повторення та закріплення, що показує на практиці потрібність знань у подальшому процесі пізнання. У свою чергу, усвідомлення потрібності знань зміцнює інтерес до їх поглиблення й розширення. Звертаючись до знань із суміжних предметів, викладач спонукає учнів до переносу знань і способів дій у нові пізнавальні ситуації, активізуючи мисленнєві процеси аналізу й синтезу, порівняння, узагальнення та класифікації.

\section{Література}

1. Абдуллина О. А. Общепедагогическая подготовка учителя в системе высшего педагогического образования / Оксана Алексеевна Абдуллина. - [2-е изд., перераб. и доп.] - М. : Просвещение, 1990. 141 с. 2. Великий тлумачний словник сучасної української мови / [уклад. і голов. ред. В. Т. Бусел]. К. : Перун, 2003. - 1440 с. 3. Ганелин Ш. И. Дидактический принцип сознательности / Шолом Израилевич Ганелин. - М. : АПН РСФСР, 1961. - 78 с. 4. Гончаренко С. У. Український педагогічний словник / Семен Устимович Гончаренко. - К. : Либідь, 1997. - 376 с. 5. Леонтьев А. Н. Деятельность. Сознание. Личность / Алексей Николаевич Леонтьев. - М.: Политиздат, 1977. - 303 с. 